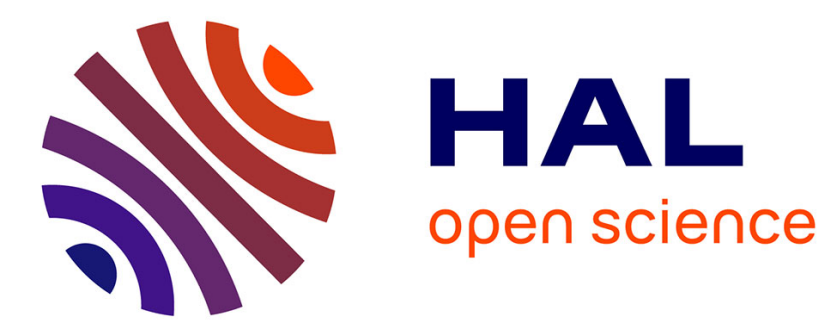

\title{
Social utility and desirability of internal and external employees: insights for collaboration at work \\ Crisanta-Alina Mazilescu, Bernard Gangloff
}

\section{To cite this version:}

Crisanta-Alina Mazilescu, Bernard Gangloff. Social utility and desirability of internal and external employees: insights for collaboration at work. Psihologia Resurselor Umane, 2017, 15 (1), pp.69 - 79. 10.24837/pru.2017.1.6 . hal-01693389

\section{HAL Id: hal-01693389 \\ https://hal.parisnanterre.fr/hal-01693389}

Submitted on 26 Jan 2018

HAL is a multi-disciplinary open access archive for the deposit and dissemination of scientific research documents, whether they are published or not. The documents may come from teaching and research institutions in France or abroad, or from public or private research centers.
L'archive ouverte pluridisciplinaire HAL, est destinée au dépôt et à la diffusion de documents scientifiques de niveau recherche, publiés ou non, émanant des établissements d'enseignement et de recherche français ou étrangers, des laboratoires publics ou privés. 


\title{
Social utility and desirability of internal and external employees: insights for collaboration at work
}

\author{
CRISANTA-ALINA MAZILESCU \\ Politehnica University Timisoara, Timișoara, Romania \\ Université de Paris Ouest-Nanterre La Défense, Nanterre Cedex, France \\ BERNARD GANGLOFF \\ Université de Paris Ouest-Nanterre La Défense, Nanterre Cedex, France
}

\begin{abstract}
Numerous studies have shown that internal explanations are preferred to external ones. After taking into consideration that this emphasis of the actor's importance resulted from a bias, it was argued that it was rather the proof of a social norm: the norm of internality. Nevertheless, research tending to highlight the existence of this norm seems, in the case of certain authors, to be accompanied by a methodological bias that invalidates them. However, to confer on an object the status of a social norm means to assign a value (in terms of desirability and utility) to that object. This study aims to verify once more the existence of an internality norm, by employing a novel procedure of examining the value attributed to internality. One hundred and seventy employees were questioned on the desirability and utility they would confer to a future work colleague. They had to assess the social value of a future co-worker on the basis of the answers given by this colleague to an internality / externality questionnaire. The results show that the internal individuals are almost always preferred to external ones, both in terms of desirability and utility, regardless of the future status (peer vs. subordinate) of that collaborator. But it should be emphasized that this preference for the internal individuals is solely a function of a predominance of the positive judgments passed on the internal individuals, and not of a negative evaluation of the external ones. This means that the external ones are not stigmatized.
\end{abstract}

\section{Keywords}

internality, social desirability, social utility

\section{Introduction}

The internal/external dichotomy is known for a long time and it is used for two purposes: to explain the sanctions received (i.e., Locus of Control, or LOC, Lefcourt and Rotter, 1966), and to explain the behaviours adopted (i.e., causal attribution, Heider, 1944, 1958; Jones \& Davis, 1965; Kelley, 1967). In terms of LOC, this dichotomy leads to the conclusion that a penalty, positive or negative, can be explained either internally (the receiver of the sanction is said to be the cause of it, due to his personality or behaviour), or externally (in which case the cause invoked is an element external to the receiver of the sanction, such as circumstances, chance, luck or bad luck, fate, or Acts of God, etc.). Similarly, in terms of assignment, a behaviour may be explained either internally ("I wanted to adopt such a conduct"), or externally ("the circumstances pushed me to it"). 
Initially, the research in this area was carried out within the framework of differential psychology: it has lead to the conclusion that certain people are, due to their personality, internal (therefore with a tendency to use internal explanations), while others are more external. However, it was also found that individuals were more frequently internal than external. The work conducted on this dichotomy has shown that when trying to determine the causes of a certain behaviour, success or failure, there is often the tendency to look at the actor, with the tendency to overestimate the influence of internal factors at the expense of external ones. Therefore, the individuals generally believe (and assess) themselves to be more responsible for what happens to them (Lerner, 1965; Lerner \& Simmons, 1966; Langer, 1975) and for what they do (Ross, 1977; Jones, 1979), than they actually are.

Since childhood, and especially at school, the pupils learn that to be well seen they have to show themselves interne (Dubois \& Poultier, 1991; Py \& Somat, 1991).

In the organizational environment, there is, also, a valorization of the interns, whatever the style of management and the hierarchical status of the evaluator (Beauvois, Bourjade \& Pansu 1991). An internal performer is preferred to an external performer, internality being more important than the performance at work. (Pansu, 1994). The social work institutions judge more positively the interns and attribute them a better success in obtaining a job (Beauvois \& Le Poultier, 1986).

Generally, internal individuals are more valued by society compared to external ones, they are more recruited, more praised, more appreciated in their work, as the external individuals are rejected, even if they are performing.

The overestimation of the actor's share has long been interpreted as an involuntary error due to failures of reasoning. This was the case in the $19^{\text {th }}$ century, when Nietzsche spoke of a "fundamental error" (Nietzsche, French ed. 1968, p.163), and more recently Heider (1944, p. 361) and Ross (1977), who used the term "fundamental attribution error". This analysis in terms of error and bias was nevertheless challenged during the 1980's, when the concept of a norm of internality was introduced; first by Jellisson and Green (1981), through the causality of reinforcements, then by Beauvois (1984), in terms of explaining both reinforcements and behaviours. This new analysis means that the overestimation observed in terms of actor's share would be the consequence of a social valuation of such internal explanations. This internality norm was more precisely defined as the "(social) valuation of explanations of psychological events (behaviours and reinforcements) that accentuate the share of the actor as a causal factor" (Dubois 1987, p. 175). Many then attempted, using various procedures, to demonstrate the existence of this norm. The judges' paradigm has thus been used, which entailed the establishing of a prognosis of academic or professional success for a target known for their more or less proven adherence to internality (Beauvois, Bourjade \& Pansu, 1991; Bressoux \& Pansu, 1998; Desrumaux, 2005; Dubois \& Le Poultier, 1991; Pansu, 1997; Pansu \& Gilibert, 2002). The paradigm of self-presentation was also used, where the participants are invited to give the best image versus the worst image of themselves to an evaluative authority, the internal responses being considered to be related to the right image and the external responses to the wrong image (Bressoux \& Pansu, 2003; Dompnier \& Pansu, 2007, 2010; Jouffre, Py \& Somat, 2008; Pansu \& Gilibert, 2002). Similarly, the paradigm of identification invites the participants to expose their judgements in their own name, and then as they believe that other people would, with answers being more often internal for oneself than for others (Beauvois, Gilibert, Pansu, \& Abdellaoui, 1998; Pansu, Tarquinio, \& Gilibert, 2005).

However, other studies demonstrated the non-systematic nature of such valuation of internal explanations (Cueillens \& Castra, 1998; Dagot \& Castra, 2002; Lecigne, 2008; Louche, 1998). More fundamentally, the empirical works of Gangloff (1997) and Demas (2009) have shown, consistently, that the studies meant to demonstrate the existence of such a norm were biased, and that such bias was likely to collapse "the greatest part of the underpinnings of the internality norm" (Delmas, 2009, p67). Gangloff (1997) pointed out that the research tending to prove the 
existence of the internality norm jointly varied the valence of internal and external items. He has shown that by reversing this valence we arrive at a norm of externality rather than internality. Similarly, based on several questionnaires classically used to study the internality norm, Delmas (2009) has demonstrated that the internal items systematically had a more positive valence than the external ones. Evidently, this does not mean that the existence of such a norm should be avoided, but rather that it can only be considered as a hypothesis. It is in this context that we find ourselves. Taking into consideration that assigning a norm status to an object means that said object has value (Dubois, 1994), if internality has value, this article the questions the value assigned to internal and, respectively, to external explanations, on the assumption that the former will be attributed more value than the latter. The validation of this hypothesis would then support the existence of the norm of internality and confirm that there are indeed biases in the previous studies which led to the reversal of this validity.

Let us begin by recalling that to assert that an object has value means that the object is on the one hand desirable and, on the other hand, useful (Beauvois, Dubois, \& Peeters, 1999). Desirability is oriented on the agreeable, attractive, pleasant character of the and on their relational value, while utility would refer to the faculty of the object assessed to achieve its objectives (Peeters, 1986, speaks of "profitability for oneself"), or to allow the society as a whole, to achieve its objectives (Beauvois, 1995, speaks of "social utility"). Therefore, at least in terms of utility, there would be one differentiation on the conceptual level. However, this differentiation would not be found on an empirical level: according to a study by Cambon, Djouary and Beauvois (2006), the characteristics profitable for oneself would be equally useful for the society ${ }^{1}$. Based on this, Cassignol-Bertrand and Constant (2007) have thus asked teachers to indicate the utility and desirability that they would attribute to pupils defined as intrinsically or extrinsically motivated. Gangloff and Mazilescu (2015) have asked employees to indicate the utility and desirability that they would attribute to a colleague according to said colleague's degree of belief in a just world. Mazilescu, Gangloff and Auzoult (2011), as well as Mazilescu and Gangloff (2012), have questioned students on the utility and desirability that they would attribute to a person according to said person's responses to each of the Big Five traits. Studies have also focused on the utility and desirability attributed to obtaining information on an individual's personality traits (for example, Mazilescu, Abdellaoui and Gangloff, 2012) or to obtaining information on the degree of internality/externality of a person (e.g., Gangloff, 2010). Evidently, we are directly interested in this study on internality. More precisely, the study dealt with indicating if obtaining information on the degree of internality of such a colleague was perceived as enjoyable or useful. And it was observed that even if such information might be unpleasant (which proved to be the case especially when such information revealed an external positioning of the future colleague), it was generally considered useful (particularly because it allowed, within the framework of future interactions with such a colleague, to anticipate their reactions). On the other hand, it also appeared that such judgments (which attested the independence between desirability and utility) varied according to whether the target to be evaluated was a future subordinate or a future peer (with especially more strict judgements of desirability and utility when they regarded a subordinate than when they regarded a peer). However, a limitation of this study is that it excluded the study of the value attributed to internality: its objective was only to examine whether it is enjoyable or useful to know that we will be working with an internal vs. an external colleague (and not to examine whether working with an internal or external colleague was perceived as enjoyable or useful).

In fact, to our knowledge, only three studies directly address the value attributed to

\footnotetext{
${ }^{1}$ As to the relationships between desirability and utility, they remain unknown: Le Barbenchon, Cambon and Lavigne (2005) underline that the results obtained based on such relationships are contradictory, some showing positive correlations, others negative correlations and yet others the total absence of correlations.
} 
an individual's internality/externality. They are presented by Grimault (2015) as part of his doctoral thesis. She asked a group of students to indicate the value they attributed to some candidates for employment according to the degree of internality / externality of these candidates. However, in two of these studies (which are similar, except for the job title used), the results are contradictory: if, in terms of utility, the internal candidate is judged positively and the external candidate is judged neutrally, on the other hand, in one of these studies, the internal individual is judged as being more useful than the external one, whereas in the second study there is no differentiation between them. As for desirability judgements, no significant difference was observed between the candidates, each of the two judgments being either positive (within one study) or neutral (within the second study). Finally, in the third study the students were asked to judge candidates according to the latter's responses to eight situations (four positive and four negative) and the results showed that the observed differences between the two targets are more attributable to the valence of the situations rather than to the internal/external variable. The internal individual is more valued than the external one (both in terms of utility and desirability), only in positive valence events. This valuation comes from a predominance of positive evaluations for the internal individuals and a predominance of neutral evaluations for the external ones. Moreover, for events bearing a negative valence, the external individual is considered more useful than the internal one (with a negative appreciation, as compared to a neutral judgement for the internal individual, while the external one benefits from a neutral judgement) and in terms of desirability, the two targets are not distinguished, both of them being devalued as compared to a neutral judgment. Therefore, the third study demonstrated once more, but by using value as a dependent variable, the methodological bias, related to the valence of the items, previously proven by Gangloff (1997) and Delmas (2009). However, the deceptive results of Grimault (2015) may have stemmed only from his tool for measuring value.
In fact, several instruments can be used. The four scales developed by Le Barbenchon, Cambon and Lavigne (2005): two scales of utility (participants were asked whether a target characterized by a certain adjective "has everything they need in order to succeed in their professional life" vs. "has nothing they need in order to succeed in their professional life", and "has a high wage" vs. "has a low wage") and two of desirability (participants had to indicate whether the target "has everything they need in order to be loved" $v s$. "has nothing they need in order to be loved" and "has many friends" vs. "has few friends"). These scales were summarized by Grimault (2015) in his third study. However, certain authors (e.g., Gangloff, 2010) have considered these scales to be somewhat reductive by taking into consideration, for example in the case of utility, only useful versus useless behaviours, that is, forgetting about the harmful behaviours (which Beauvois, 1976, called "perverse" conducts). Thus, "having everything they need in order to succeed in life" seems to be as much the opposite of "having nothing they need in order to succeed in life" as "having everything they need in order to fail in life". And similar reasoning can be offered for desirability (for "has a lot of friends", one could be suggested not only "has few friends", but also "has many enemies"; not to mention that one could at the same time have many friends and many enemies). Other authors (for e.g., Gangloff, 2010; Gangloff \& Mazilescu, 2015; Mazilescu, Abdellaoui \& Gangloff, 2012) proposed more direct and less reductionist scales employing "pleasant, indifferent or unpleasant" (for desirability), and "useful, uninteresting or annoying" (for utility).

Therefore, it seemed relevant to examine once more the value attributed to internality, but having as participants employees and using the following question: Is having to work with an internal (vs. external) colleague considered enjoyable and useful? More simply put, the question is about knowing if an internal colleague ( $v s$. an external one) is considered to be an enjoyable and useful colleague. Moreover, taking into consideration that Gangloff's results (2010) varied according to the status of the target to be evaluated, we have also considered that the 
value granted to internality may vary depending on whether the target was a subordinate or a peer.

\section{Method}

We asked 170 employees (only men), which we contacted at their workplace, to provide answers individually and voluntarily for two items (on desirability and on utility). They had to assess the social value of a future colleague, in terms of desirability and utility, based on the answers given by said colleague to an internality / externality questionnaire.

Specifically, 89 respondents were supervisors (50 were asked to analyse the profile of a future internal subordinate and 39 the profile of a future external subordinate) and 81 respondents lacking a hierarchical responsibility (40 were confronted with the profile of a future internal peer and 41 with the profile of a future external peer).

The questionnaire, presented in the form of paper and pencil, to which this future colleague was supposed to have answered is the LOC questionnaire created by Gangloff and Sourisse (1995). It includes 24 items (12 internal and 12 external): to annexes 1 and 2.

These were the instructions given to the respondents: «In the following questionnaire, you are asked to imagine that you will soon have a new work colleague (vs. a new subordinate). You have very little information on this person: you do not know if they are male or female, or their age, etc. In the following pages you can however read some answers this person has given to a questionnaire, during a skills assessment. You learn, for example, that this person has said: "I am a dynamic, ambitious person, who loves challenges". You will then have to indicate: on the one hand if you consider that it will be pleasant, indifferent or unpleasant for you to work with this person, and to explain why; and on the other hand if you believe that person will be useful, useless or, on the contrary, that they will interfere with your work, and explain why.»

The responses given by the future colleague and afterwards the questions on desirability and utility followed:

"1. Do you think that if you would work with this person, you would find them...

- pleasant:

- somebody who leaves you indifferent:

- unpleasant:

Why?

2. Do you think that if you would work with this person, they would be useful to you, or useless, or that they would interfere with your work?

- useful:

- useless:

- interfering:

Why?

\section{Results}

The judgments of the desirability and utility made by 170 employees starting from the answers that a future colleague was supposed to have given to a questionnaire on internality/externality were presented in terms of occurrences in following tables: 
Table 1. Distribution of answers obtained (occurrences of the positives, neutral and negative judgments)

\begin{tabular}{llcccccccc}
\hline & & \multicolumn{3}{c}{ Desirability } & \multicolumn{5}{c}{ Utility } \\
\cline { 3 - 9 } & & + & 0 & - & total & + & 0 & - & total \\
\hline \multirow{2}{*}{ Internal } & Peer & 16 & 12 & 12 & 40 & 24 & 8 & 8 & 40 \\
& Sub & 23 & 9 & 18 & 50 & 36 & 6 & 8 & 50 \\
& Total & 39 & 21 & 30 & 90 & 60 & 14 & 16 & 90 \\
\hline \multirow{2}{*}{ External } & Peer & 3 & 22 & 16 & 41 & 9 & 16 & 16 & 41 \\
& Sub & 4 & 21 & 14 & 39 & 4 & 25 & 10 & 39 \\
& Total & 7 & 43 & 30 & 80 & 13 & 41 & 26 & 80 \\
\hline \multirow{2}{*}{ Total } & Peer & 19 & 34 & 28 & 81 & 33 & 24 & 24 & 81 \\
& Sub & 27 & 30 & 32 & 89 & 40 & 31 & 18 & 89 \\
& Total & 46 & 64 & 60 & 170 & 73 & 55 & 42 & 170 \\
\hline
\end{tabular}

The answers were analysed on SPSS, with Anova and $d$ of Cohen (using: .0 to $.35=$ negligible effect; .35 to $.65=$ intermediate effect; $>.65=$ notable effect).

\subsection{The effect of the status}

It appears first of all, both in terms of desirability, as well as utility, that the judgments passed on a future subordinate are identical to those passed on a future peer, with one exception in what concerns the judgments of neutral utility passed on external targets: their frequency is significantly higher for subordinates $(M=0.64)$ than for peers $(M=0.39), F(1.78)=5.23 ; p=0.02 ; d=0.51$.

\subsection{The effect of internality}

Nevertheless, our main interest is the possible effect of internality. Therefore, our results show numerous significant differences, the judgments on internal collaborators being almost always more favourable than those passed on external collaborators.

On a global level (Table 2), the internal individuals are judged more favourably than the external ones, both in terms of desirability (respectively $M=2.10$ and $M=1.71$ ) as well as utility (respectively $M=2.49$ and $M=1.84$ ).

Table 2. Means and effects of internality

\begin{tabular}{lccccl}
\hline \multicolumn{1}{c}{$\begin{array}{c}\text { Subjects } \\
\text { target }\end{array}$} & \multicolumn{2}{c}{ Desirability } & \multicolumn{2}{c}{ Utility } & $\mathrm{F}$ (Snedecor) and d (Cohen) \\
\hline & Internal & External & Internal & External & \\
\hline global & 2.10 & 1.71 & - & - & $F(1.168)=10.62 ; p=.001 ; d=.51$ \\
global & - & - & 2.49 & 1.84 & $F(1.168)=31.74 ; p \approx .00 ; d=.89$ \\
subordinates & 2.10 & 1.74 & - & - & $F(1.87)=4.33 ; p=.04 ; d=.45$ \\
subordinates & - & - & 2.56 & 1.85 & $F(1.87)=23.46 ; p \approx .00 ; d=1.05$ \\
peers & 2.1 & 1.68 & & & $F(1.79)=6.55 ; p=.012 ; d=.57$ \\
peers & & & 2.4 & 1.83 & $F(1.79)=10.55 ; p=.002 ; d=.72$ \\
\hline
\end{tabular}


In terms of desirability (Table 3), these differences come from more positive evaluations passed on internal individuals than on external ones (respectively $M=0.43$ and $M=0.09$ ), as well as than from a low frequency of neutral judgments passed on the former ( $M=0.23$ versus $M=0.54)$. On the other hand, there is no significant difference concerning negative judgments $(M=0,33$ et $M=0,38 ; \mathrm{ns})$.

Table 3. Means and effects of internal/external desirability

\begin{tabular}{|c|c|c|c|c|c|c|c|}
\hline \multirow{2}{*}{$\begin{array}{l}\text { Subjects } \\
\text { target }\end{array}$} & \multicolumn{3}{|c|}{$\begin{array}{l}\text { Level of } \\
\text { internal desirability }\end{array}$} & \multicolumn{3}{|c|}{$\begin{array}{l}\text { Level of } \\
\text { external desirability }\end{array}$} & \multirow[t]{2}{*}{ F (Snedecor) and d (Cohen) } \\
\hline & positive & neutral & negative & positive & neutral & gative & \\
\hline $\begin{array}{l}\text { subjects } \\
\text { global }\end{array}$ & 0.43 & - & - & 0.09 & - & - & $F(1.168)=28.81 ; p \approx .00 ; d=.85$ \\
\hline $\begin{array}{l}\text { subjects } \\
\text { global }\end{array}$ & - & 0.23 & - & - & 0.54 & - & $F(1.168)=17.34 ; p \approx .00 ; d=.65$ \\
\hline subordinates & 0.46 & - & - & 0.10 & - & - & $F(1.87)=15.21 ; p \approx .00 ; d=.86$ \\
\hline subordinates & - & 0.18 & - & - & 0.54 & - & $F(1.87)=14.35 ; p \approx .00 ; d=.8$ \\
\hline peers & 0.4 & - & - & 0.07 & - & - & $F(1.79)=13.80 ; p \approx .00 ; d=.82$ \\
\hline peers & - & 0.3 & - & - & 0.54 & - & $F(1.79)=4.81 ; p=.03 ; d=.49)$ \\
\hline
\end{tabular}

As for the results on utility (Table 4), they follow an identical pattern, with differences coming both from more positive evaluations of internal individuals, as opposed to external ones (respectively $M=0.67$ and $M=0.16$ ), and from a low frequency of neutral judgements passed on the former $(M=0.16$ versus $M=0.51)$ and also from a low frequency of negative judgments passed on the former $(M=0.18$ versus $M=0.33$ ).

Table 4. Means and effects of internal/external utility

\begin{tabular}{|c|c|c|c|c|c|c|c|}
\hline \multirow{2}{*}{$\begin{array}{l}\text { Subjects } \\
\text { target }\end{array}$} & \multicolumn{3}{|c|}{$\begin{array}{c}\text { Level of } \\
\text { internal utility }\end{array}$} & \multicolumn{3}{|c|}{$\begin{array}{c}\text { Level of } \\
\text { external utility }\end{array}$} & \multirow[t]{2}{*}{ F (Snedecor) and d (Cohen) } \\
\hline & positive & neutral & negative & positive & neutral & egative & \\
\hline $\begin{array}{l}\text { subjects } \\
\text { global }\end{array}$ & 0.67 & - & - & 0.16 & - & - & $F(1.168)=57.42 ; p \approx .00 ; d=1.18$ \\
\hline $\begin{array}{l}\text { subjects } \\
\text { global }\end{array}$ & - & 0.16 & - & - & 0.51 & - & $F(1.168)=29.06 ; p \approx .00 ; d=.81)$ \\
\hline $\begin{array}{l}\text { subjects } \\
\text { global }\end{array}$ & - & - & 0.18 & - & - & 0.33 & $F(1.168)=4.73 ; p=.03 ; d=.34$ \\
\hline subordinates & 0.72 & - & - & 0.10 & - & - & $F(1.87)=53.16 ; p \approx .00 ; d=1.59$ \\
\hline subordinates & - & 0.12 & - & - & 0.64 & - & $F(1.87)=36.30 ; p \approx .00 ; d=1.26$ \\
\hline peers & 0.6 & - & - & 0.22 & - & - & $F(1.79)=13.93 ; p \approx .00 ; d=.8)$ \\
\hline
\end{tabular}


More specifically, in what concerns the subordinates, the internal individuals are always better evaluated than the external ones, both in terms of desirability (respectively $M=2.10$ versus $M=1.74)$ and utility $(M=2.56$ and $M=1.85$ ) (Table 2). In terms of desirability (Table 3), this preference results from a higher frequency of positive judgments on internal individuals $(M=0.46$ versus $M=0.10$ for external ones), and from a lower frequency of neutral judgments on the former $(M=0.18$ versus $M=0.54$ ). In terms of utility (Table 4 ), they come both from a higher frequency of positive judgments on internals $(M=0.72$ versus $M=0.10$ for externals) and from fewer neutral judgements on the former, as compared to the latter (respectively $M=0.12$ and $M=0.64$ ). With regard to negative judgments, there is no significant difference between internals and externals, neither in desirability $(M=0,36$ for internals and externals) nor in utility ( $M=0,16$ and $M=0,26$; ns).

In what concerns future peers, the internal individuals are always better evaluated than the external ones, both in terms of desirability (respectively $M=2.1$ versus $M=1.68$ ) and utility ( $M=2.4$ and $M=1.83$ ) (Table 2). In terms of desirability (Table 3 ), this preference comes essentially from a higher frequency of positive judgments passed on internal individuals $(M=0.4)$ than on external ones $(M=0.07)$, but also from a lower frequency of neutral judgments passed on the former $(M=0.3$ versus $M=0.54)$. And the same can be said about utility (Table 4), where there are also more positive judgements passed on internal individuals $(M=0.6)$ than on external ones $(M=0.22)$. Once again, with regard to negative judgments, there is no significant difference between internals and externals, neither in desirability $(M=0,30$ and $M=0,39$; ns $)$ nor in utility ( $M=0,20$ et $M=0,39$; ns).

\section{Discussion and conclusion}

Regardless of the level of internality, and both in terms of desirability and utility, it appears that the evaluation of the value of a future peer are generally identical to the ones made on a subordinate: there is no status effect.

Turning now to our main question, meaning the effect of internality, our results highlight the numerous significant differences in favour of judgments almost always more favourable for future internal collaborators than for future external collaborators, in terms of both desirability and utility. We also observe that the results relate both to future subordinates and to future peers. In other words, future collaborators, whether peers or subordinates, are considered more useful and more desirable when they are internal than when they are external.

In the introduction we mentioned several works that indicate that internality was sometimes considered to be a social norm, but also certain methodological critiques of the studies conducted in order to attempt to verify the validity of this hypothesis. However, as we outlined in the introduction as well, to confer an object the status of a social norm means to assign value (in terms of desirability and utility) to that object (Dubois, 1994). These results confirm the assignment of value and therefore the possible existence of such an internality norm. Thus, on a theoretical level, our results provide an incentive to continue the work meant to validate the existence of such a potential norm. But our results should also make us reflect, still on a theoretical level, on the possible absence of a corollary relation between valuation and devaluation. In fact, we emphasize the fact that the differences observed herein between internal and external individuals are usually the result not so much of more frequent negative judgments (as compared to neutral judgements) passed on external individuals, but rather of more positive judgments passed on internal individuals: therefore, there would not be any real stigmatization of external individuals, but rather a valuation of the internal ones. Indeed, on an applied level, it may be appropriate to see this as a preference (in terms of agreeability and utility) for working with internal collaborators, while considering the external individuals to be realists, which may lead to not rejecting them systematically. We mention again that for Beauvois (1984, p. 133), "internality has at least as a virtual corollary the non-questioning of the environment [thus preserving social situations] of the perception that one may have of one's arbitrariness". In other words, the 
valuation of internality would be based on the absence of criticism of the social environment, and in particular on the absence of criticism of the hierarchy of powers: attributing their situation to themselves rather than to external elements, the internal individuals preserve in fact the environment of any criticism. On a practical level, for example, in what regards recruitment, this means that choosing between an internal $v s$. an external collaborator would then depend on the degree to which the organisational hierarchy is ready to accept any possible questioning of its management. This implies that future research should take into account the organisational culture and, in particular, its degree of openness to criticism.

However, our results have certain limitations. In addition to not taking into account the organisational culture, which we have just mentioned, we have also not contextualized the job position held by the future collaborators. It is obvious that expectations may differ according to the type of position exercised by such a future collaborator, be it a future peer or a future subordinate. It would then be appropriate, in a later study, to refine this aspect and to vary the job position in order to operationalize the form of the independent variable. Another important limitation of this study is the lack of measurement of the internality level of our participants. It is not excluded that they themselves may have been more internal than external. If this were the case, they might have had the tendency to attribute more value to targets similar to themselves, that is, to internal targets. Shaver (1970) thus evokes the possibility of an attributive bias arising from the relevance of similarity between the evaluator and the evaluated target. It would therefore be necessary, in subsequent studies, to verify the correct distribution of the participants' internality degree.

\section{References}

Beauvois, J-L. (1976). Problématiques des conduites sociales d'évaluation. Connexions, 19, 7-30.

Beauvois, J-L. (1984). La psychologie quotidienne. Paris: PUF.

Beauvois, J-L. (1995). La connaissance des utilités sociales. Psychologie française, 40, 375-388.
Beauvois, J. L., Bourjade, A., \& Pansu, P. (1991). Norme d'internalité et évaluation professionnelle. Revue Internationale de Psychologie Sociale, 4(1-2), 9-28.

Beauvois, J-L., Dubois, N., \& Peeters, G. (1999). L'évaluation personnologique. In J-L. Beauvois, N. Dubois \& W. Doise (Eds). La construction sociale de la personne. Grenoble: PUG, 259-279.

Beauvois J.-L. \& Le Poultier F. (1986) Norme d'internalité et pouvoir en psychologie quotidienne. Recherches sur la psychologie de tous les jours. Revue Française de Psychologie 31, 2 (100-108).

Bressoux, P., \& Pansu, P. (1998). Norme d'internalité et activités évaluatives en milieu scolaire. Revue Française de Pédagogie, 122, 19-29.

Bressoux, P., \& Pansu, P. (2003). Quand les enseignants jugent leurs élèves. Paris: Presses Universitaires de France.

Beauvois, J. L., Gilibert, D., Pansu, P., \& Abdelaoui, S. (1998). Internality attribution and intergroup relations. European Journal of Social Psychology, 28(2), 123-140.

Cambon, L., Djouary, N., \& Beauvois, J-L. (2006). Social norms of judgment and social utility: when it is more profitable to be useful than desirable. Swiss Journal of Psychology, 65, 167-180.

Cassignol-Bertrand, F., \& Constant, E. (2007). La norme de motivation intrinsèque : valorisation, utilité et désirabilité sociales, Bulletin de psychologie, 448(2), 121-133.

Cueillens, C., \& Castra, D. (1998). Norme d'internalité et sphères de vie. Psychologie du Travail et des Organisations, 4(1-2), 44-53.

Dagot, L., \& Castra, D. (2002). L'allégeance : un principe des logiques d'aide à l'insertion professionnelle. L'orientation Scolaire et Professionnelle, 31(3), 417442.

Delmas, F. (2009). La norme d'internalité : critique de la méthode. Revue Internationale de Psychologie Sociale, 1, 39-73.

Desrumaux, P. (2005). Informations normatives et stéréotypiques: effets de l'internalité/externalité, du genre, de l'apparence physique et du type hiérarchique et sexuel du poste sur les décisions de recrutement. Revue Internationale de Psychologie Sociale, 18(4), 165-199.

Dompnier, B., \& Pansu. P. (2007). L'intervention des explications internes en termes d'effort dans les stratégies d'autoprésentation et le jugement social : perspectives sociocognitives. Psychologie française, 52(4), 459-478.

Dompnier, B., \& Pansu, P. (2010). La valeur sociale des explications causales en contexte éducatif: autoprésentation des élèves et représentation des enseignants. Swiss Journal of Psychology, 69(1), 3749.

Dubois, N. (1987). La psychologie du contrôle : les croyances internes et externes. Grenoble: PUG.

Dubois, N. (1994). La norme d'internalité et le libéralisme. Grenoble: PUG

Dubois, N., \& Le Poultier, F. (1991). Internalité et évaluation scolaire. In J. L. Beauvois, R. V. Joule \& J. M. Monteil (dir.), Perspectives cognitives et conduites sociales (Vol. 3, p. 153-166). Cousset: DelVal. 
Gangloff, B. (1997). Les implications théoriques d'un choix d'items : de la norme d'internalité à la norme d'allégeance. Pratiques Psychologiques, 2, 99-106.

Gangloff, B. (2010). Utilité et désirabilité d'informations normatives sur des subordonnés et des collègues de travail. Les cahiers de Psychologie Politique, $\mathrm{n}^{\circ} 17$. [http://www.cahierspsypol.fr].

Gangloff, B., \& Mazilescu, C-A. (2015). Is it desirable or useful to believe in a just world? Revista de Cercetare si Interventie Sociala, 51,150-161.

Gangloff, B., \& Sourisse, M. (1995). Influence de la durée du chômage et des stages chômeurs longue durée sur l'évolution du conformisme à la norme d'internalité. Psychologie et Psychométrie, Revue de Langue Française, 16(3), 5-19.

Grimault, V. (2015). La dichotomie entre les jugements d'utilité et de désirabilité relative aux normes sociales. Thèse de doctorat, Université Paris 10.

Heider, F. (1944). Social perception and phenomenal causality, Psychological Review, 51, 358-374.

Heider, F. (1958). The psychology of interpersonal relations. New-York: Wiley.

Jellison, J.M., \& Green, J. (1981). A self-presentation approach to the fundamental attribution error: the norm of internality. Journal of Personality and Social Psychology, 40, 4, 643-649.

Jones, E.E. (1979). The rocky road from acts to dispositions. American Psychologist, 34(2), 107-117.

Jones, E.E., \& Davis, K.E. (1965). From acts to dispositions. The attribution process in person perception. In L. Berkowitz (Ed.). Advances in experimental social psychology. New-York: Academic Press, vol. 2, 219-266.

Jouffre, S., Py, J., \& Somat, A. (2008). Academic judgment and institutional evaluation made by teachers according to pupils' explanatory activity. European Journal of Psychology Education, 23(4), $399-420$

Kelley, H.H. (1967). Attribution in social psychology. In L. Levine (Ed.). Nebraska symposium on motivation. Lincoln: University of Nebraska Press, vol. 15, 192238.

Langer E.J. (1975). The illusion of control. Journal of Personality and Social Psychology, 32_(2), 311-328.

Le Barbenchon, E., Cambon, L., \& Lavigne, F. (2005). Désirabilité et utilité sociale de 308 adjectifs de personnalité et 297 professions. L'année Psychologique, 105, 307-322.

Lecigne, A. (2008). Allégeance à l'école et intérêt de l'enfant : le cas de Jean. Le Journal des Psychologues, $58,68-71$.

Lefcourt, H. M. (1966). Internal vs external control of reinforcement; A review. Psychological Bulletin, 65, 206-220.

Lerner, M.J. (1965). Evaluation of performance as a function of performer's reward and attractiveness. Journal of Personality and Social Psychology, 1, 355-360.
Lerner, M.J., \& Simmons C.H. (1966). Observer's reaction to the «innocent victim»: compassion or rejection? Journal of Personality and Social Psychology, 4(2), 203-210.

Louche, C. (1998). The norm of internality and coordination mechanisms in organizations. Revue Européenne de Psychologie Appliquée, 48(3), 189192.

Mazilescu, C-A., Abdellaoui, S., \& Gangloff, B. (2012). Assessing the Social Value of Personality Information. Revista de Cercetare si Interventie Sociala, 38, 91-106.

Mazilescu, C-A., \& Gangloff, B. (2012). Natural descriptors: a study on social desirability and social utility. International Journal of Academic Research, 4(2), 11-16.

Mazilescu, C-A., Gangloff, B. \& Auzoult, L. (2011). Désirabilité et utilité sociales des traits du Big Five. Psihologia Sociala, 28(11), 33-51.

Nietzsche, F. (Ed. française 1968). Humain trop Humain. Paris: Gallimard, vol 1.

Pansu, P. (1994). La norme d'internalité et le jugement sur la valeur professionnelle. Thèse de Doctorat, document non publié. Laboratoire de Psychologie Sociale. Université Pierre Mendès France, Grenoble 2.

Pansu, P. (1997). Norme d'internalité et appréciation de la valeur professionnelle: l'effet des explications internes dans l'appréciation du personnel. Le Travail Humain, 60(2), 205-222.

Pansu, P., \& Gilibert, D. (2002). Effect of causal explanations on work-related judgment. Applied Psychology: An International Review, 51(4), 505526. doi: 10.1111/1464-0597.00105

Pansu, P., Tarquinio, C., \& Gilibert, D. (2005). Internal attributions in an intergroup business setting. Le Travail Humain, 68(1), 55-72.

Peeters, G. (1986). Good and evil as softwares of the brain: on psychological immediates underlying the metaphysical ultimates. Interdisciplinarystudies in the philosophy of understanding, 9, 210-231.

Py J. \& Somat A. (1991). Normativité, conformité et clairvoyance : leurs effets sur le jugement évaluatif dans un contexte scolaire. In Beauvois (J.L.), Joule (R.V.) et Monteil (J.M.) (Eds), Perspectives cognitives et conduites sociales, 3, 167-193.

Ross, L. (1977). The intuitive psychologist and his shortcomings : distorsions in the attribution process. In L. Berkowitz (Ed.). Advances in experimental social psychology. New-York: Academic Press, vol.10, 173-220.

Rotter, J. B. (1966). Generalized expectancies for internal versus external control of reinforcement. Psychological Monographs, 80(609), 1-28.

Shaver, K.G. (1970). Defensive attribution: effects of severity and relevance on the responsibility assigned for an accident. Journal of Personality and Social Psychology, 14(2), 101-113. 


\section{Annex 1: internal items}

Imagine that you will soon have a new work colleague ( $v s$. a new subordinate), and that the only information you have on that person is that they said:

1. If they have will, the unemployed people would definitely find a job.

2. When people get what they want at work, it is usually because they have really done everything to obtain it.

3. When we make some efforts, most of the times, we will find a job.

4. Most of the times when people fail in their work, it is due to lack of abilities, lack of work or perseverance on their part.

5. Most of the times when people do not get, within their company, the job position they want, it is because they lack the necessary skills.

6. Capable people who fail to advance in their career have not taken advantage of the opportunities presented to them.

7. Most often, the problems people encounter in their professional life come from errors they have committed.

8. Most often, people who fail to find employment owe it to their personality or their lack of skills.

9. If people have good results in their work, it is because of their personality or skills.

10. Professional success is directly related to an individual's abilities.

11. In their professional life, if somebody is capable and hardworking, they will almost always be able to achieve their objectives.

12. People whose professional qualities are not recognized are those who have not sought to get them recognized.

\section{Annex 2: external items}

Imagine that you will soon have a new work colleague ( $v s$. a new subordinate), and that the only information you have on that person is that they said:

1. Most of the people who are unable to find work owe it to purely fortuitous events.

2. During a job interview, having a head that pleases the person in charge with recruitment strongly favours hiring.

3. Most people who managed to advance in their career should thank chance.

4. Fate being what it is, if it's a bad day, people who have a job interview have low chances of being hired.

5. In most cases, it is chance or uncontrolled elements that prevent people from finding a job.

6. Most often, when a person who responds to a job offer succeeds in getting hired means they are lucky: they were lucky to get there at the right time.

7. Professional success is related to the goodwill of the people we depend on.

8. If a work day starts well, it will be fine anyway.

9. Without luck, one cannot acquire new responsibilities in one's work.

10. Most of the people who have an interesting job are lucky: they had the chance to get an interesting job offer.

11. The difficulties faced by people who are looking for a job are partly due to bad luck.

12. Numerous failures during job interviews are explained by a character conflict between the job seeker and the person in charge with recruitment. 